\title{
PERSEPSI DAN PERILAKU PRODUSEN DAN KONSUMEN TERHADAP LABEL ASAL DAERAH PADA MANGGA GEDONG GINCU
}

\author{
Yosini Deliana, Sri Fatimah, dan Anne Charina
}

Jurusan Sosial Ekonomi, Fakultas Pertanian, Universitas Padjadjaran

J1.Raya Jatinangor Km.21 Sumedang

yosini22@yahoo.com

\begin{abstract}
ABSTRAK Mangga gedong gincu (Mangifere indica var.Gedong) banyak diusahakan di Jawa Barat dengan sentra produksi Indramayu, Majalengka dan Cirebon. Hasil penelitian lapangan mengungkapkan bahwa mangga gedong gincu dari Majalengka dan Cirebon lebih diminati konsumen daripada Gedong gincu dari Indramayu, karena bentuknya lebih bulat, warnanya lebih menarik dan aromanya lebih tajam (Deliana, 2011). Masalahnya adalah tidak ada jaminan kualitas bahwa mangga tersebut memiliki kematangan tertentu, rasa dan bebas hama seperti harapan konsumen. Sejak tahun 2005 pedagang besar di Kabupaten Majalengka, Cirebon dan Indramayu mencoba menempelkan label pada mangga gedong Gincu, tapi bukan label asal daerah. Label asal daerah hanya dikeluarkan oleh Dinas Pertanian setempat dan hanya digunakan mangga Gedong Gincu pada saat pameran atau sebagai oleh-oleh kepada tamu khusus yang berkunjung ke daerah tersebut. Penelitian dilakukan dari bulan Juli sampai dengan September 2013 di Kecamatan Sedonglor Kabupaten Cirebon karena banyak pelaku pasar sudah menggunakan label. Sampel petani diambil secara acak sebanyak 30 orang, 30 konsumen Cirebon dan 200 konsumen Bandung. Hasil penelitian mengungkapkan bahwa produsen dan konsumen mengganggap penting label asal daerah, akan tetapiprodusen maupun konsumen tidak mengetahui bahwa label asal daerah seharusnya menunjukkan informasi tanggal petik, informasi letak kebun, informasi asal daerah dan sebagai persyaratan untuk ekspor. Untuk meningkatkan pemasaran mangga, harus ada program yang terintegrasi dan adanya saling keterkaitan antara konsumen, produsen, pelaku pasar, dan penentu kebijakan. Harapannya ke depan, origin labeling dapat dikembangkan menjadi Country of Origin labeling (COOL) dan menjadi titik awal untuk internasionalisasi mangga di pasar global
\end{abstract}

Kata kunci : Persepsi, perilaku, produsen, konsumen dan label asal daerah

\section{PERCEPTION AND BEHAVIOR OF PRODUCER AND CONSUMER OF GEDONG GINCU MANGO TO ORIGIN LABELING}

\begin{abstract}
The previous research show that gedong gincu mangos from Majalengka, Cirebon and Cirebon are prefered by consumers to those from Indramayu because they have rounder shape, more attractive color, and stronger aroma (Deliana, 2011). The main problem of marketing mangos is that there is no guarantee for consumers regarding mango quality so that they are not prepared to pay premium prices for quality mangos. The study was conducted from July to September 2013 in the district of Cirebon Sedonglor because several the market agents have already used labels. Samples were taken at random farmer of 30 people, while 30 people in Cirecon and 200 people in Bandung were taken as consumer. The study showed that origin labeling is importan based on producer and consumer perception, but they did not know that origin labeling should give the information of harvesting date, farming location, labeling information and requirement for export. For improving the mango market, it should be integrated program and interrelationship between consumers, producers, traders, and policy makers. Hopefully in the future, origin labeling can be improved as to Country of Origin Labeling (COOL) and this is the starting point for the internationalization of mangoes in the global market
\end{abstract}

Key words : Perception, behavior, producer, consumer and origin labelling

\section{PENDAHULUAN}

Negara produsen terbesar mangga di dunia adalah India dengan share sekitar 40,5\%, diikuti oleh China sekitar 11,7 \% dan Thailand sekitar 6,9\%. Di Asia ,Indonesia negara keenam produsen mangga dengan share sekitar $3.5 \%$ pada produksi dunia dengan pertumbuhan sekitar $47 \%$. Posisi mangga sangat penting bagi perkembangan hortikultura di Indonesia. Kontribusi total buah terhadap Produk Domestik Brotu (PDB) sekitar 35.449,46 milyar $(48,36 \%)$, hanya saja sejak sepuluh tahun terakhir mengalami penurunan. Disisi lain permintaan buah buahan di Indonesia pun meningkat, peningkatan selama lima tahun terakhir $10 \%$ (Natawidjaja, 2009). Hal ini karena sebagian besar masyarakat Indonesia mulai menggalakan pola hidup sehat dengan mengkonsumsi makanan sehat seperti sayuran dan buah-buahan. Walaupun Indonesia negara penting penghasil mangga di Asia, akan tetapi ekspor mangga terus meningkat, data menunjukkan pada tahun 2000 ekspor mangga hanya 64 ton, akan tetapi pada tahun 2010 mencapai 1.129 ton, terjadi peningkatan sekitar $200 \%$ (BPS, 2009). Hal ini sangat ironis sekali terjadi di Indonesia yang lahannya potensial untuk ditanami mangga.

Produksi mangga di Indonesia naik turun dengan varietas yang banyak, tidak adanya jaminan kualitas dan keseragaman produk sehingga kurang komersial baik untuk pasar nasional maupun internasional. Menurut Nawawidjaja, (2012) volume export tidak stabil karena terbatasnya ketersediaan mangga berkualitas tinggi sehingga exportir tidak berani 
kontrak kuantitas (expor seadanya mangga tersedia). Pada Gambar 1 terlihat bahwa ekspor mangga turun, padahal mangga gedong gincu potensial untuk ekspor. Menurunnya ekspor karena kualitas yang bervariasi dan tidak kontinyunya pasokan. Sealin itu juga harga mangga gedong gincu berfluktuasi, dari sisi produsen keadaan ini tidak menggairahkan untuk memproduksi mangga, supply kurang, konsumen pada akhirnya memilih mangga impor walaupun sebenarnya mangga lokal lebih disukai (Deliana, 2011). Hasil penelitian Trina et al., (2008) mengemukakan bahwa pedagang besar mendapatkan keuntungan dari perbedaan harga pasar dengan harga eksportir. Akibatnya petani tidak mendapatkan harga yang lebih tinggi seperti dijanjikan eksportir dan akhirnya petani tidak termotivasi untuk meningkatkan kualitas. Ekspor mangga masih terkendala karena tidak seragamnya kualitas, produktivitas rendah, varietas lokal kurang komersial secara local maupun internasional, petani mangusahakan mangga tidak komersial, harga di tingkat petani sangat murah dan industri kesulitan bahan baku diluar masa panen utama, kerusakan pada saat pengiriman masih sangat tinggi dan petani kurang tepat menerapkan teknologi karena tidak didasarkan aplikasi teknologi yang lengkap (Wandschneider.,Ian Baker and Natawidjaja, 2012)

Produsen mangga terbesar di Indonesia adalah Jawa Timur, Jawa Tengah, Jawa Barat, Sulawesi Selatan, NTB dan NTT. Mangga gedong gincu (Mangifere indica var.Gedong) banyak diusahakan di Jawa Barat dengan sentra produksi Indramayu, Majalengka dan Cirebon. Mangga gedong gincu memiliki keunikan dalam hal rasa, bentuk dan aroma. Hasil penelitian lapangan mengungkapkan bahwa mangga gedong gincu dari Majalengka dan Cirebon lebih diminati konsumen daripada Gedong gincu dari Indramayu, karena bentuknya lebih bulat, warnanya lebih menarik dan aromanya lebih tajam (Deliana, 2011). Mangga sangat bervariasi baik dalam variaetas maupun rasa serta tidak adanya jamiman kualitas. Apabila konsumen mengetahui dengan pasti darimana asal mangga tersebut dan yakin akan kualitasnya (adanya origin labeling), maka konsumen akan membayar dengan harga premium dan akhirnya petani akan mendapatkan keuntungan lebih (Deliana, 2012). Konsumen adalah raja dan pemasaran menjadi hal terpenting dalam keberlanjutan agribisnis mangga, dan untuk keberhasilan pasar mangga harus adanya saling keterkaitan antara konsumen, produsen, pelaku pasar, dan penentu kebijakan. Dengan demikian penelitian ini penting dilakukan sebagai upaya untuk meningkatkan kesejahteraan petani mangga. Selanjutnya origin labeling ditingkatkan menjadi Country of Origin labeling (COOL) dan menjadi titik awal untuk internasionalisasi mangga di pasar global.

\section{Identifikasi Masalah.}

1. Apakah label asal daerah penting dilakukan menurut produsen, stakeholder, instansi pemerintah dan instansi terkait, konsumen industri dan konsumen rumah tangga?
2. Apa keuntungan dan kerugian diberlakukannya label asal daerah?

3. Klater produsen dan konsumen mana yang mengetahui manfaat dari albel asal daerah?

\section{METODE PENELITIAN}

Data yang digunakan dalam penelitian ini adalah data primer dan data sekunder. Data primer merupakan data yang diperoleh dari petani mangga yang subsisten, petani transisional dan petani komersial, pelaku pasar seperti pedagang pengumpul, pedagang kecil dan pedagang besar, pelaku pasar supermarket, konsumen pasar tradisional, konsumen supermarket dan konsumen industri. Selain itu dilakukan indepth study kepada key person, stakeholder dan instansi terkait. Sedangkan data sekunder dari Badan Pusat Statistik, dan sumber data lainnya.

Sampel petani dan konsumen dilakukan dengan metode simple random sampling dengan jumlah sampel produsen (petani, pedagang pengumpul dan pedagang besar sebanyak 30 orang, jumlah sampel konsumen dari Kabupaten Cirebon sebanyak 30 orang dan sebagai perbandingan dilakukan hal yang sama untuk konsumen di Kota Bandung sebanyak 200 orang dengan alasan dari hasil penjajagan lapangan diperoleh informasi bahwa mangga gedong gincu dari Kabupaten Cirebon banyak didistribusikan ke Kota Bandung. Identifikasi masalah satu dan dua dianalisis secara deskriptif sedangkan identifikasi masalah ketiga dengan klaster analisis dan ukuran similaritas yang digunakan sebagai berikut :

$$
S M(x, y)=\frac{a+d}{a+b+c+d}
$$

dimana a, b c dan d adalah frekuensi pada tabel kontingensi berikut:

\begin{tabular}{lcl}
\hline \multicolumn{3}{c}{ Karakteristik 2} \\
\hline Karakteristik 1 & Ya & Tidak \\
Ya & A & b \\
Tidak & c & d \\
\hline
\end{tabular}

\section{HASIL DAN PEMBAHASAN}

Umumnya pedagang pengumpul maupun pedagang besar merangkap sebagai petani, dan pohon mangga yang dimiliki yang memiliki pohon mangga gedong gincu antara $1-50$ pohon $(56 \%)$, antara $51-150(31 \%)$ dan antara $150-250$ pohon $(13 \%)$. Dalam 1 hektar lahan bisa diusahakan sekitar 100 pohon mangga gedong gincu, dengan demikian ratarata lahan yang diusahakan untuk mangga gedong gincu dibawah 0.5 ha.

Pendidikan petani umumnya adalah Sekolah Dasar (43\%), SLTP (31\%) dan SLTA (26\%), dengan rata-rata penghasilan per bulan antara $2-3,9$ Juta $(87 \%), 4-6$ Juta (8\%) dan lebih besar dari 6 Juta $(5 \%)$. Sedangkan rata-rata jumlah anggota keluarga antara $3-5$ orang $(65 \%)$, lebih kecil dari 3 anggota keluarga $(20 \%)$ dan lebih besar dari 5 anggota keluarga (15\%). Rata-rata petani mangga sudah 
mengusahakan mangga dengan baik, ada sekitar 23 kelompoktani yang sudah sudah mengusahakan lahannya dengan menerapkan Good Agricultural Practices (GAP).

Pendidikan Konsumen pada umumnya adalah SLTA (53\%), dan Stata 1 (29\%), dan SLTP (18\%). Rata-rata penghasilan per bulan $2-3$ Juta $(15 \%)$, 4 - 6 Juta (38\%) dan $<6$ Juta (47\%). Sedangkan rata-rata jumlah anggota keluarga lebih kecil dari 3 anggota keluarga (59\%) antara 3 - 5 orang ( $32 \%$ ), dan lebih besar dari 5 anggota keluarga (9\%). Umur responden bervariasi, pada umumnya antara $25-35$ tahun (67\%), sisanya menyebar dibawah 25 tahun (5 $\%$ ) dan diatas 35 tahun ( $28 \%$ ).

\section{Persepsi Tingkat Kepentingan Label asal Daerah}

Menurut Schiffman dan Kanuk (2004) pengertian persepsi adalah proses yang dirasakan seseorang dalam memilih, mengorganisasikan dan menginterpretasikan suatu yang dialaminya menjadi suatu gambaran yang berarti dan lengkap tentang dunianya. Ada dua faktor utama dalam persepsi yaitu faktor stimulus atau rangsangan dan faktor individual. Hal yang sama dikemukakan oleh Stephen (2006) dan Siti et al (2003) bahwa persepsi adalah proses yang digunakan individu mengelola dan menafsirkan kesan indera mereka dalam rangka memberikan makna kepada lingkungannya. Dengan demikian pesepsi produsen dan konsumen terhadap label asal daerah adalah pendapat produsen dan konsumen tentang label asal daerah, apakah penting untuk dilakukan, bagaimana pendapatnya mengenai keuntungan dan kerugian apabila label asal daerah ini diberlalukan dan bagaimana harapan dari produsen dan konsumen dengan adanya label asal daerah tersebut.

Petani dan pedagang pengumpul pada umumnya merasa penting adanya label asal daerah, akan tetapi ada juga beberapa petani dan pedagang pengumpul yang berpendapat tidak penting. Petani yang menganggap tidak penting karena petani tersebut mengganggap bahwa dengan adanya label asal daerah tidak memberikan tambahan keuntungan yang significan, selain itu ada tanggung jawab untuk selalu menjaga kualitas. Pedagang besar atau supplier pada umumnya berpendapat bahwa label asal daerah ini penting, dan pedagang besar yang berpendapat tidak penting adalah pedagang besar yang sudah memiliki konsumen yang tetap, sudah menjadi pelanggan gedong gincu. Jadi konsumen ini hanya dengan menelpon maka mangga gedong gincu bisa diantar maupun diposkan ke luar kota seperti halnya Jakarta dan Bandung. Dengan demikian label asal daerah bukan menjadi issue yang penting, karena konsumen sudah tahu dari kebun yang mana, siapa pemilik kebunnya, jadi ada kepercayaan dari konsumen. Eksportir, Dinas Pertanian Tanaman Pangan Kabupaten dan Dinas Pertanian Propinsi menganggap label asal daerah wajib dilakukan, hal ini untuk mempromosikan mangga gedong gincu menjadi icon bagi daerahnya. Sedangkan bagi konsumen industri atau olahan, mangga gedong gincu yang diperlukan yang kualitas BS sehingga tidak perlu label asal daerah. Konsumen merasa penting adanya label asal daerah untuk memastikan bahwa produknya berkualitas dan aman untuk dikonsumsi. Konsumen yang menganggap bahwa label asal daerah tidak penting adalah bagi konsumen disekitar produsen mangga gedong gincu. Konsumen ini sudah yakin dengan kualitas dan keamanan pangannya sehingga tidak perlu ada label asal daerah.

Tabel 1. Pendapat produsen, Konsumen dan Stakeholder akan Pentingnya Label Asal Daerah

\begin{tabular}{lcc}
\hline & Penting $(\%)$ & Tidak penting $(\%)$ \\
\hline Petani & 75 & 25 \\
Pedagang pengumpul & 85 & 15 \\
Pedagang besar & 90 & 10 \\
Eksportir & 100 & - \\
Konsumen industri & - & 100 \\
Konsumen akhir & 72 & 28 \\
Dinas Pertanian Tanaman & 100 & - \\
Pangan Kabupaten & & - \\
Dinas Pertanian Tanaman & 100 & \\
Pangan Propinsi & & \\
\hline
\end{tabular}

Hasil penelitian Maepace et.al (2009) tentang respon konsumen akan pentingnya Country of Origin Label pada produk segar adalah $80 \%$ penting, $8 \%$ tidak penting dan $12 \%$ tidak tahu. Sedangkan untuk product olahan $76 \%$ penting, $11 \%$ tidak penting dan $13 \%$ tidak tahu. Di Amerika origin label ini menguntungkan petani dan konsumen, selain itu dengan diberlakukannya origin label impor buah menjadi berkurang, karena konsumen bangga dengan produk daerahnya. Persepsi diantara konsumen menjadi sangat penting dalam origin label karena persepsi bisa menentukan keputusan konsumen untuk membeli (Schupp and Gillespie, 2000). Di negara yang sudah maju seperti Amerika, label asal daerah ini dianggap penting, akan tetapi bagaimana halnya dengan negara berkembang. Dengan diketahuinya informasi ini menjadi dasar bagi produsen untuk menentukan konsumen mana yang akan dituju dengan adanya label asal daerah tersebut

\section{Tanggapan tentang Keuntungan dan Kerugian Label Asal Daerah}

Keuntungan label asal darah menurut pedagang pengumpul adalah adanya kepercayaan konsumen, untuk menunjukkan bahwa gedong gincu lebih unggul dan berbeda dengan gedong gincu dari tempat lain, dan untuk promosi. Bagi konsumen buah berlabel lebih terjamin kualitasnya, konsumen merasa lebih bergengsi pada saat membeli buah berlabel, terutama apabila buah tersebut dibuat parcel, karena yakin bahwa buah yang diberikan tersebut kualitasnya terjamin. Ada kecenderungan bagi konsumen golongan menengah ke atas kenaikan harga tidak menjadi masalah untuk buah berlabel. Dengan adanya label asal daerah konsumen percaya akan kualitas buah tersebut dan percaya bahwa buah tersebut aman untuk dikonsumsi karena penggunaan pestisidan dan pemupukan yang berimbang. Apabila 
musim mangga sekitar bulan Oktober dan Desember konsumen akan menambah pembelian 1 - 3 kilogram per bulan. Sedangkan pada saat mangga tidak musim sekitar bulan April sampai Juni, sehingga harga mangga naik maka biasanya konsumen akan membeli buah pengganti. Buah pengganti umumnya pisang $(56 \%)$, pepaya $(32 \%)$ dan lainnya (12\%). Pisang dan pepaya menjadi buah substitusi mangga karena harganya murah dan selalu ada setiap saat. Bagi konsumen golongan menengah ke bawah dan jumlah anggota keluarga yang cukup banyak, maka kenaikan harga karena kualitas tidak menjadi pertimbangan, kelompok konsumen ini lebih memperhatikan kuantitas daripada kualitas.

Kerugian label asal daerah adalah adanya konsekuensi dan tanggung jawab untuk selalu menjaga nama label. Apabila nama label asal daerah tercemar maka untuk mengembalikan nama baik tersebut memerlukan biaya dan waktu yang lama. Apabila mangga gedong gincu dicitrakan menjadi buah yang eksotis maka tentunya apabila ada satu pedagang yang melanggar komitmen maka citra mangga gedong gincu sebagai buah eksotis tidak ada lagi. Untuk menbuat citra inipun dibutuhkan waktu dan biaya yang banyak dan harus diposisikan kembali pencitraan tersebut atau bahkan dibuat label yang baru untuk meraih kepecayaan konsumen. Selain itu dengan adanya label asal daerah, apabila ada keluhan konsumen dalam hal rasa, aroma, warna maupun penampilan harus direspon produsen dengan cepat, padahal kita ketahui bahwa sifat produk pertanian itu ada gestination period. Gestination period dalam hal ini ada jarak waktu antara waktu tanam dan waktu panen, berbeda halnya dengan produk industri yang hasilnya sesuai dengan harapan. Selain itu menurut pedagang untuk mendapatkan label asal daerah proses dan persyaratannya nya sulit, sehingga perlu dilakukan sosialisasi tentang label asal daerah tersebut. Pedagang juga khawatir apabila diterapkan label asal daerah, korbanan biaya untuk label, pembersihan, standarisasi., grading, pengemasan dan penyimpanan tidak sebanding dengan harga yang diterima. Kekhawatiran ini menyebabkan petani lebih bersikap risk averter menjalankan cara pemasaran yang saat ini dijalaninya. Petani,pedagang pengumpul harus diberi pengetahuan tentang label asal daerah, oleh sebab itu peneltian selanjutnya ingin melihat apabila produsen dan konsumen diberi pengetahuan akan segala sesuatu tenang label asal daerah, apa saja yang akan berubah. Lebih dalam lagi kaitannya dengan indikasi geografis, sampai sejauh mana produsen merespon keinginan konsumen.

\section{Harapan adanya Label Asal Daerah}

Harapan produsen dengan adanya label asal daerah adalah pendapatannyameningkat dan bisamempromosikan produk ungggulan dari daerahnya. Sedangkan hambatan produsen untuk mengimplementasikan label asal daerah adalah harus selalu menjaga kualitas, padahal sumber daya manusia dan keterampilannya terbatas (38\%), belum adanya kesepakatan informasi apa yang seharusnya ada dalam label asal daerah, (24\%), ada kemungkinan peningkatan pendapatan dengan adanya label asal daerah belum signifikan (20\%) dan willingness to pay konsumen masih rendah $(8 \%)$

Harapan konsumen akan label asal daerah adalah yang utama berturut-turut adanya jaminan kualitas, mudah didapatkan, harganya terjangkau dan adanya lembaga yang mengawasi keberlangsungan label asal daerah ini. Menurut konsumen apabila tidak ada lembaga yang mengawasi, maka produsen dengan mudah membohongi konsumen, selain itu apabila ada keluhan dari konsumen maka lembaga tersebut bisa memfasilitasi. Konsumen akan membayar lebih mangga gedong gincu tergantung banyak faktor diantaranya daya beli, pendapatan, selera, terpenuhi apa yang diharapkannya, dan konsumen merasa prestise dalam membeli produk tersebut. Di lapangan juga terungkap bahwa konsumen mau membayar lebih untuk label asal daerah umumnya naik $10 \%$ dari harga pasar saat ini, walaupun ada juga konsumen yang mau membayar lebih dari $40 \%$. Sebagai wacana adanya kecenderungan konsumen membayar lebih besar lagi untuk mangga yang memiliki indikasi geografi, karena konsumen lebih percaya pada indikasi geografis daripada label asal daerah. Indikasi Geografis adalah suatu tanda yang menunjukkan daerah asal suatu barang, yang karena faktor lingkungan geografis termasuk faktor alam, faktor manusia, atau kombinasi kedua faktor tersebut, memberikan ciri dan kualitas tertentupada barang yang dihasilkan. Hal ini tercantum dalam PP. No.51 Tahun 2007 Pasal 1 ayat 1.

\section{Cluster Produsen dan Konsumen yang Mengetahui Manfaat dari Label asal Daerah}

Label asal daerah diambil dari terminologi Country of labellling yaitu label yang menunjukkan bahwa produk tersebut berasal, diproduksi atau diproses di negara tersebut, akan tetapi bisa juga dibudidayakan, diolah atau dikemas di negara lain. Misalnya kiwi diproduksi oleh New Zealand akan tetapi dibuat syrup kiwi di Amerika, maka dalam label dicantumkan bahwa Country of labelling nya New Zealand dan diberi keterangan bahwa telah diolah dan diproduksi di Amerika. Dengan demikian yang dimaksud dengan label asal daerah adalah label yang menandakan bahwa produk tersebut berasal dari daerah tersebut, seperti halnya apel Malang berasal dari Kota Malang. Label adalah bagian dari atribute produk yang menginformasikan karakteristik suatu produk.

Berikut adalah hasil output SPSS pengelompokan produsen maupun konsumen menjadi dua yaitu kelompok yang mengetahui manfaat label asal daerah dan kelompok yang tidak mengetahui manfaat label asal daerah. Hal ini yang ditunjukkan dengan variabel variabel yang dipersepsikan oleh produsen dan konsumen yang seharusnya ada pada label asal daerah. 
Tabel 2. Cluster Produsen dan Konsumen yang Mengetahui Manfaat Label Asal Daerah

\begin{tabular}{llll}
\hline \multicolumn{1}{c}{ Faktor } & Produsen & $\begin{array}{c}\text { Konsumen } \\
\text { Cirebon }\end{array}$ & $\begin{array}{c}\text { Konsumen } \\
\text { Bandung }\end{array}$ \\
\hline Kesegaran & Mengetahui & Mengetahui & Mengetahui \\
Kadar Air & Tidak & Mengetahui & Mengetahui \\
Aroma Khas & Mengetahui & Mengetahui & Mengetahui \\
Vitamin Lengkap & Tidak & Mengetahui & Mengetahui \\
Rasa Khas & Mengetahui & Mengetahui & Mengetahui \\
Matangpohon & Tidak & Mengetahui & Mengetahui \\
Tidak mengandung pupuk kimia & Mengetahui & Mengetahui & Mengetahui \\
Tidak mengandung pupuk kimia & Mengetahui & Mengetahui & Mengetahui \\
Informasi tanggal petik & Tidak & Tidak & Tidak \\
Informasi letak Kebun & Tidak & Tidak & Tidak \\
Informasi asal daerah & Tidak & Tidak & Tidak \\
Meningkatkan harga & Mengetahui & Mengetahui & Mengetahui \\
Persyaratan Ekspor & Tidak & Tidak & Tidak \\
Target Pasar yangjelas & Mengetahui & Mengetahui & Mengetahui \\
Segmen Pasar yangjelas & Tidak & Tidak & Mengetahui \\
Alat Promosi & Mengetahui & Mengetahui & Mengetahui \\
\hline
\end{tabular}

Ada tiga macam label yaitu (1) grade label adalah label yang menunjukkan tingkat kualitas tertentu suatu produk, (2)description label or informative label adalah label yang menggambarkan cara penggunaan atau menginformasikan hal pentinglainnya berkaitan dengan label dan (3) brand label adalah label yang berfungsi sebagai brand, (Golam et al , 2000; Umberger et al, 2005). Dalam penelitian ini, grade label diantaranya kesegaran, kadar air, aroma, kandungan vitamin, rasa, tidak mengandung pestisida dan pupuk kimia. Informative label diantaranya informasi tanggal petik, letak kebun dan asal daerah, sedangkan brand label diantaranya untuk meningkatkan harga, persyaratan ekspor, target pasar, segmen pasar dan alat informasi

Dari Tabel 2 terlihat bahwa untuk klaster produsen yang mengetahui manfaat label origin adalah produsen yang memiliki persepsi bahwa label asal daerah bisa menunjukkan kesegaran buah,aroma yang khas, rasa yang khas, tidak mengandung pestisida, tidak mengandung pupuk kimia, dapat meningkatkan harga, target pasar yang jelas dan sebagai alat promosi (Analisis data pada Tabel 3)

Tabel 3. Produsen Cirebon Proximity Matrix

\begin{tabular}{|c|c|c|c|c|c|c|c|c|c|c|c|c|c|c|c|c|c|}
\hline \multirow{2}{*}{ No } & \multirow{2}{*}{ Case } & \multicolumn{16}{|c|}{ Matrix File input } \\
\hline & & 1 & 2 & 3 & 4 & 5 & 6 & 7 & 8 & 9 & 10 & 11 & 12 & 13 & 14 & 15 & 16 \\
\hline 1 & Kesegaran & 1.000 & .600 & .767 & .133 & .733 & .133 & .733 & .633 & .133 & .333 & .300 & .133 & .133 & .867 & .133 & .667 \\
\hline 2 & Kadar air & .600 & 1.000 & .500 & .467 & .600 & .467 & .533 & .967 & .467 & .733 & .700 & .467 & .467 & .533 & .467 & .533 \\
\hline 3 & Aroma & .767 & .500 & 1.000 & .167 & .700 & .167 & .767 & .533 & .167 & .300 & .267 & .167 & .167 & .833 & .167 & .700 \\
\hline 4 & Vitamin & .133 & .467 & .167 & 1.000 & .133 & 1.000 & .133 & .433 & 1.000 & .733 & .767 & 1.000 & 1.000 & .000 & 1.000 & .200 \\
\hline 5 & Rasa & .733 & .600 & .700 & .133 & 1.000 & .133 & .733 & .633 & .133 & .400 & .367 & .133 & .133 & .867 & .133 & .667 \\
\hline 6 & Kematangan & .133 & .467 & .167 & 1.000 & .133 & 1.000 & .133 & .433 & 1.000 & .733 & .767 & 1.000 & 1.000 & .000 & 1.000 & .200 \\
\hline 7 & Tidak pestisida & .733 & .533 & .767 & .133 & .733 & .133 & 1.000 & .567 & .133 & .267 & .300 & .133 & .133 & .867 & .133 & .733 \\
\hline 8 & Tidak pupuk & .633 & .967 & .533 & .433 & .633 & .433 & .567 & 1.000 & .433 & .700 & .667 & .433 & .433 & .567 & .433 & .567 \\
\hline 9 & Lolos SNI & .133 & .467 & .167 & 1.000 & .133 & 1.000 & .133 & .433 & 1.000 & .733 & .767 & 1.000 & 1.000 & .000 & 1.000 & .200 \\
\hline 10 & Letak kebun & .333 & .733 & .300 & .733 & .400 & .733 & .267 & .700 & .733 & 1.000 & .967 & .733 & .733 & .267 & .733 & .333 \\
\hline 11 & Asal daerah & .300 & .700 & .267 & .767 & .367 & .767 & .300 & .667 & .767 & .967 & 1.000 & .767 & .767 & .233 & .767 & .300 \\
\hline 12 & Harga & .133 & .467 & .167 & 1.000 & .133 & 1.000 & .133 & .433 & 1.000 & .733 & .767 & 1.000 & 1.000 & .000 & 1.000 & .200 \\
\hline 13 & Ekspor & .133 & .467 & .167 & 1.000 & .133 & 1.000 & .133 & .433 & 1.000 & .733 & .767 & 1.000 & 1.000 & .000 & 1.000 & .200 \\
\hline 14 & Target pasar & .867 & .533 & .833 & .000 & .867 & .000 & .867 & .567 & .000 & .267 & .233 & .000 & .000 & 1.000 & .000 & .800 \\
\hline 15 & Segmen pasar & .133 & .467 & .167 & 1.000 & .133 & 1.000 & .133 & .433 & 1.000 & .733 & .767 & 1.000 & 1.000 & .000 & 1.000 & .200 \\
\hline 16 & Promosi & .667 & .533 & .700 & 0,2 & .667 & .200 & .733 & .567 & .200 & .333 & .300 & .200 & .200 & .800 & .200 & 1.000 \\
\hline
\end{tabular}

Klaster konsumen Cirebon yang mengetahui manfaat label origin adalah konsumen yang memiliki persepsi bahwa label asal daerah menunjukkan kesegaran buah, kadar air yang banyak, aroma yang khas, rasa yang khas, matang pohon, tidak mengandung pestisida, tidak mengandung pupuk, dapat meningkatkan harga, target pasar yang jelas, dan untuk promosi (Analisis data pada Tabel 4).

Tabel 4. Konsumen Cirebon Proximity Matrix

\begin{tabular}{|c|c|c|c|c|c|c|c|c|c|c|c|c|c|c|c|c|c|}
\hline \multicolumn{18}{|c|}{ Proximity Matrix } \\
\hline \multirow{2}{*}{ No } & \multirow{2}{*}{ Case } & \multicolumn{16}{|c|}{ Matrix File input } \\
\hline & & 1 & 2 & 3 & 4 & 5 & 6 & 7 & 8 & 9 & 10 & 11 & 12 & 13 & 14 & 15 & 16 \\
\hline 1 & Kesegaran & 1.000 & .900 & .733 & .900 & .867 & .867 & .900 & .900 & .567 & .567 & .567 & .900 & .433 & .900 & .867 & .767 \\
\hline 2 & Kadar air & .900 & 1.000 & .767 & .933 & .833 & .900 & .933 & .933 & .600 & .600 & .600 & .933 & .400 & .933 & .900 & .800 \\
\hline 3 & Aroma & .733 & .767 & 1.000 & .767 & .667 & .733 & .767 & .833 & .500 & .500 & .500 & .767 & .500 & .767 & .733 & .700 \\
\hline 4 & Vitamin & .900 & .933 & .767 & 1.000 & .833 & .900 & .933 & .933 & .600 & .600 & .600 & .933 & .400 & .933 & .900 & .800 \\
\hline 5 & Rasa & .867 & .833 & .667 & .833 & 1.000 & .800 & .833 & .833 & .433 & .433 & .433 & .833 & .567 & .833 & .800 & .700 \\
\hline 6 & Kematangan & .867 & .900 & .733 & .900 & .800 & 1.000 & .900 & .900 & .567 & .567 & .567 & .900 & .433 & .900 & .867 & .900 \\
\hline 7 & Tidak pestisida & .900 & .933 & .767 & .933 & .833 & .900 & 1.000 & .933 & .600 & .600 & .600 & .933 & .400 & .933 & .900 & .800 \\
\hline 8 & Tidak pupuk & .900 & .933 & .833 & .933 & .833 & .900 & .933 & 1.000 & .533 & .533 & .533 & .933 & .467 & .933 & .900 & .800 \\
\hline 9 & Lolos SNI & .567 & .600 & .500 & .600 & .433 & .567 & .600 & .533 & 1.000 & 1.000 & 1.000 & .533 & .000 & .533 & .567 & .600 \\
\hline 10 & Letak kebun & .567 & .600 & .500 & .600 & .433 & .567 & .600 & .533 & 1.000 & 1.000 & 1.000 & .533 & .000 & .533 & .567 & .600 \\
\hline 11 & Asal daerah & .567 & .600 & .500 & .600 & .433 & .567 & .600 & .533 & 1.000 & 1.000 & 1.000 & .533 & .000 & .533 & .567 & .600 \\
\hline 12 & Harga & .900 & .933 & .767 & .933 & .833 & .900 & .933 & .933 & .533 & .533 & .533 & 1.000 & .467 & .933 & .900 & .800 \\
\hline 13 & Ekspor & .433 & .400 & .500 & .400 & .567 & .433 & .400 & .467 & .000 & .000 & .000 & .467 & 1.000 & .467 & .433 & .400 \\
\hline 14 & Target pasar & .900 & .933 & .767 & .933 & .833 & .900 & .933 & .933 & .533 & .533 & .533 & .933 & .467 & 1.000 & .900 & .800 \\
\hline 15 & Segmen pasar & .867 & .900 & .733 & .900 & .800 & .867 & .900 & .900 & .567 & .567 & .567 & .900 & .433 & .900 & 1.000 & .767 \\
\hline 16 & Promosi & .767 & .800 & .700 & .800 & .700 & .900 & .800 & .800 & .600 & .600 & .600 & .800 & .400 & .800 & .767 & 1.000 \\
\hline
\end{tabular}


Tabel 5. Konsumen Bandung

Proximity Matrix

\begin{tabular}{|c|c|c|c|c|c|c|c|c|c|c|c|c|c|c|c|c|c|}
\hline \multirow{2}{*}{ No } & \multirow{2}{*}{ Case } & \multicolumn{16}{|c|}{ Matrix File input } \\
\hline & & 1 & 2 & 3 & 4 & 5 & 6 & 7 & 8 & 9 & 10 & 11 & 12 & 13 & 14 & 15 & 16 \\
\hline 1 & Kesegaran & 1.000 & .965 & .965 & .940 & .945 & .955 & .980 & .995 & .015 & .035 & .035 & .890 & .015 & .500 & .540 & 735 \\
\hline 3 & Aroma & .965 & .940 & 1.000 & .915 & .920 & .940 & .955 & .970 & .040 & .060 & .060 & .865 & .040 & .515 & .555 & .730 \\
\hline 4 & Vita & .940 & .925 & .915 & 1.000 & .895 & .915 & .930 & .945 & .065 & .085 & .085 & .840 & .065 & .510 & .550 & .725 \\
\hline 7 & Tida & .980 & .955 & .955 & .930 & .935 & .955 & 1.000 & .985 & .025 & .045 & .045 & .870 & .025 & .490 & .530 & .715 \\
\hline 8 & Tidak & .995 & .970 & .970 & .945 & .950 & .970 & .985 & 1.000 & .010 & .030 & .030 & .885 & .010 & .495 & .535 & .730 \\
\hline 9 & Lolos SNI & .015 & .040 & .040 & .065 & .060 & .040 & .025 & .010 & 1.000 & .960 & .960 & .105 & 1.000 & .495 & .475 & .280 \\
\hline 10 & Letak kebun & .035 & .060 & .060 & .085 & .070 & .060 & .045 & .030 & .960 & 1.000 & 1.000 & .145 & .960 & $.4 / 5$ & .495 & .300 \\
\hline 14 & Target pasar & .500 & .505 & .515 & .510 & .525 & .505 & .490 & .495 & .495 & .475 & .475 & .610 & .495 & 1.000 & .960 & .765 \\
\hline 15 & Segmen pasar & .540 & .545 & .555 & .550 & .555 & .545 & .530 & .535 & .475 & .495 & .495 & .630 & .475 & .960 & 1.000 & .805 \\
\hline 16 & Promosi & .735 & .740 & .730 & .725 & .720 & .720 & .715 & .730 & .280 & .300 & .300 & .825 & .280 & .765 & .805 & 1.000 \\
\hline
\end{tabular}

Demikian halnya dengan konsumen Bandung, hanya perbedaannya konsumen Cirebon tidak mengetahui bahwa label asal daerah bermanfaat untuk segmen pasar, karena konsumen Cirebon mengganggap yang penting adalah target pasar (Analisis data pada Tabel 5). Produsen maupun konsumen tidak mengetahui bahwa label asal daerah seharusnya menunjukkan informasi tanggal petik, informasi letak kebun, informasi asal daerah dan sebagai persyaratan untuk ekspor. Informasi ini yang seharusnya ada di label asal daerah sehingga bisa ditelusuri dari mana asalnya mangga gedong gincu tersebut. Di negara yang sudah maju informasi ini sudah lengkap dan ada dalam barcode yang tercantum dalam label asal daerah, sedangkan di Indonesia hal ini belum dilakukan karena belum tertatanya pemasaran hortikultura khususnya mangga.

\section{SIMPULAN}

Produsen dan konsumen menganggap bahwa label asal daerah ini penting untuk dilakukan. Keuntungan adanya label asal daerah adalah adanya kepercayaan konsumen, menunjukkan keunikan, dan promosi. Kerugian label asal daerah adalah adanya konsekuensi dan tanggung jawab untuk selalu menjaga nama label. Apabila nama label asal daerah tercemar maka untuk mengembalikan nama baik tersebut memerlukan biaya dan waktu yang lama

Harapan produsen dengan adanya label asal daerah adalah meningkatnya pendapatan (40\%), jaminan pasar $(32 \%)$, menambah jaringan pemasaran $(20 \%)$ dan kepastian harga (8\%). Sedangkan harapan konsumen dengan adanya label asal daerah adalah adanya jaminan kualitas (45\%), mudah didapatkan (21\%), harganya terjangkau (19\%) dan adanya pengawasan dari pihak yang berwenang( $15 \%)$.

Adanya cluster produsen dan konsumen yang mengetahui manfaat label asal daerah. Produsen maupun konsumen tidak mengetahui bahwa label asal daerah seharusnya menunjukkan informasi tanggal petik, informasi letak kebun, informasi asal daerah dan sebagai persyaratan untuk ekspor.

\section{SARAN}

Adanya kerjasama semua pihak yang berkepentingan dengan label asal daerah mulai dari pedagang pengumpul, pedagang besar, eksportir, konsumen, Dinas Pertanian Tanaman Pangan dan instansi yang terkait

Adanya edukasi ke produsen dan konsumen akan manfaat label asal daerah sehingga produsen selalu menjaga kualitas mangga dan konsumen bisa menghargainya dengan mau membayar lebih

Untuk terlaksananya label asal daerah maupun indikasi geografis, maka harus ada pembinaan yang berkesinambungan dengan program yang jelas dan terintegrasi antara Departemen Pertanian dengan Departemen terkait. Demikian pula adanya kerjasama antara pihak pemerintah, Universitas dan pihak swasta, secara teori dikenal dengan Triple Helix .

\section{DAFTAR PUSTAKA}

Deliana Y. 2011. Analysis of Consumer Behavior on the Selection of Apple, Cytrus, Imported and Local Mango, in the Bandung City, West Java. Journal Lucrari Stiintifice . Seria Agronomie. 54 (2), 32-37

2012. Do Producer and Consumer Care about Certification label on Organic Vegetable. Paper presented at Symposium on Marketing and Finance of The Organic Supply Chain- SEOUL 2012, FAO- APRACA-AFMA-IFOAM, 23-26 September

Golam, E.,F. Kuchler, L. Mitchell, C.Greene, and A.Jessup. 2000. Economics of Food labeling. Academic Research Service, U.S. Departement of Agriculture. Agriculture Eco-nomics Report no. 793. Greene, W.H. (pp. 1-36) Limpdep. Version 7.0 Plainview, N.Y. Economics Software. Inc

Johnson, Richard and Dean W Wicher. 2002. Applied Multivariate Statistical Analysis (pp.671-673). Prentice hall, Upper Saddle River, New Jersey 
Morrison, D.F. 1988. Multivariate Statistical ethods, McGraw-Hill BookCompany

Natawidjaja et al., 2009. Mango Value Chain Key Informant Interview Synthesis. Access to Modernizing Value Chains by Small Farmers in Indonesia. USAID AMA CRSP Project.

Schiffman, Leon G and L.L. Kanuk. 2004. Consumer Behavior $8^{\text {th }}$, Englewood Cliff, New Jersey. Prentice Hall Inc

Schupp, A., and J.Gillespie. 2000. Beef Handlers and a Mandatory Country of Origin labeling Requirement. Reserach Report. Lousiana Rural Economist, 62 (1), 7-8

2001. Handler Reactions to Potential Compulsary Country of Orogin labelling of Fresh and Frozen Beef. Journal Agronomi and Applied Economics, 33 (1), 161-71

Siti Nor Bayaah Ahmad dan Nurita Juhdi. 2003. Consumer 's Perception and Purchase Intentions toward Organic Food Products : Exploring the Attitude among Malaysian Consumers. Working paper, 1-15. Faculty of Business Administration, Malaysia

Stephen P. Robbin. 2006. Perilaku Organisasi, Penerbit Gramedia

Trina Fizzanty, Ray Collins and Iean Russell. 2008. Complex Adaptive Processes in Building Supply Chains : Case Studies of Fresh Mangoes in Indonesia. in Improving the Performance of Supply Chains in Transitional Economies. Responding to the Demand of Integrated Value Chains. Paper presented at International Symposium on Supply Chain Management, Chiang Main Thailand, February 3 - 6, 2008

Umberger, Wendy J, Dillon M. Freuz, Chris R. Calkins and Bethany M.Sitz. 2003. Country of Origin Labeling of Beef Products : U.S. Consumers' Perceptions. Journal of Food Distribution Research, 34(3), $103-116$

Wandschneider, Tiago, Ian Baker, and Ronnie Natawidjaja. 2012. Indonesia Agrubusiness Development Opportunities- Analysis of Mango Value Chain. AusAID- IPD Rural. 